\title{
FDI And Economic Growth Relationship In Sub-Saharan Africa: Is The Domestic Financial System A Significant Intermediator?
}

\author{
Ifeolu Oladiran Olagbaju, PhD \\ Obafemi Awolowo University Ile-Ife, Nigeria. \\ Anthony Enisan Akinlo, PhD \\ Obafemi Awolowo University Ile-Ife, Nigeria.
}

\begin{abstract}
This paper contributes to the literature on the effect of Foreign Direct Investment (FDI) on economic growth by examining the role of financial development as a source of absorptive capacity in the FDI-economic growth relationship in Sub-Saharan Africa (SSA). Using panel data econometric techniques and an unbalanced dataset of 19892013, we examine the independent effect of FDI on economic growth, as well as the impact of an interactive relationship between FDI and financial development on economic growth in SSA. We find that FDI does not directly lead to economic growth in SSA. However, the financial system through banking sector development enhances the effect of FDI on economic growth in the region. This finding is linked to the existence of a causal relationship between banking sector development and FDI, which is stronger in the low-income subsample relative to the middle-income subsample and the full SSA sample. We also estimate the threshold financial development levels essential for the expected FDI-economic growth effect to occur. Finally, the study recommends that strategies toward the attraction of foreign capital in SSA must be complemented by measures to develop the domestic financial system.
\end{abstract}

Keywords: FDI, Financial Development, Economic Growth, and Absorptive Capacity

\section{INTRODUCTION}

A significant feature of globalization over the last three decades is the remarkable rise in Foreign Direct Investment (FDI), particularly the increase in its relative importance to the economic growth of developing countries. Even though developed countries account for a greater share of FDI stock, FDI flows to the developing world have risen significantly since the '90s. For instance, in 1997, developing countries received $37.2 \%$ of FDI global flows (UNCTAD 1998, as discussed in Saggi, 2002).

In Sub-Saharan Africa (SSA) particularly, FDI has been a major source of external finance since the early '90s. Following the growth crises of the 1970s-80s, commercial bank lending had drastically reduced, leading policymakers to ease restrictions on inward penetration of foreign investments (Aitken and Harrison, 1999). Hence, many countries in the SSA region have pursued inward pro-FDI policies with the aim of deriving benefits such as new technologies, increased employment, capital inflows, and greater contact with foreign markets (Cippolina, Giovannetti, Pietrovito, and Pozzolo, 2012; Görg and Greenaway, 2004; Görg and Strobl, 2005). Consequently, FDI inflows have persistently increased in SSA since the early '90s as shown in Figure 1. 
Foreign dire ct investment, net inflows to SSA (BoP, current US\$ million)[1970-2013]

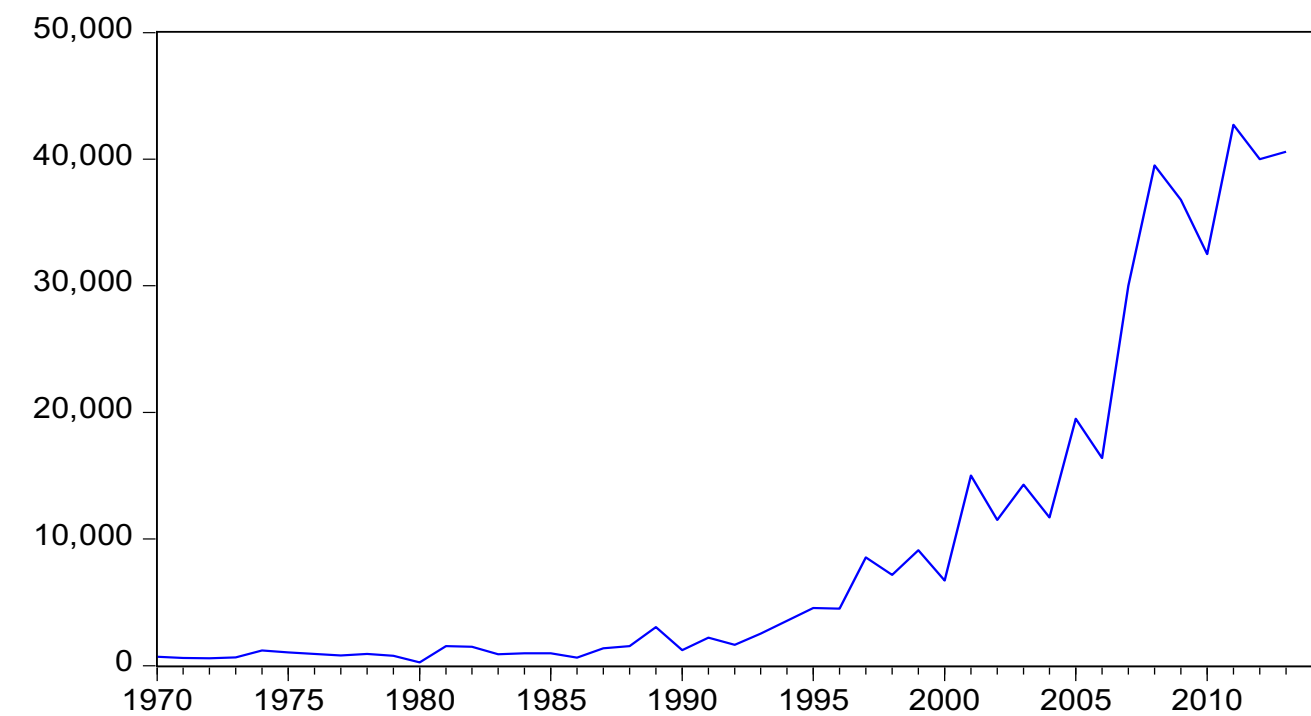

Figure 1: FDI Trend in Sub-Saharan Africa

Source: Author's computation based on World Bank's World Development Indicators (WDI, 2015)

Several studies have sought empirical evidence on the expected growth effects of FDI and find mixed evidence with many finding little evidence of a direct positive effect of FDI on economic growth (Aitken and Harrison, 1999; Carkovic and Levine, 2002). Hence, a growing body of literature suggests that the theorized growth effects of FDI do not automatically develop (Görg and Greenaway, 2004; Lipsey and Sjöholm, 2005; Smeets, 2008). Against this backdrop, factors such as existing levels of per capita GDP (Blomström, Lipsey and Zejan, 1992), trade openness (Balasubramanyam, Sapsford, and Salisu, 1996), human capital development (Borensztein, De Gregorio and Lee, 1998), have been suggested as crucial to stimulating the growth effect of FDI.

Essentially, Adams (2009) finds that FDI does not exert significant direct effect on economic growth in SSA. He noted that financial development may be a fundamental requirement for attracting and aiding the performance of FDI, following other studies that suggest that FDI is likely to enhance economic growth in host countries with better-developed financial systems (Choong, Yusop and Soo, 2004) as such countries may be successful in attracting greater and higher-quality FDI inflows. Although the financial system in SSA is by far less developed compared to other regions of the world, and even by developing country standards (Akinlo and Egbetunde, 2010; Allen, Carletti, Cull, Qian, and Senbet, 2010), it is insightful to explore its role as a facilitator of the FDI-economic growth relationship. Notably, a survey conducted by UNCTAD in $1999 / 2000$ on foreign firms in SSA reports that $28 \%$ of them lacked adequate finance, which was a major constraint as it ranked third only behind corruption (49\%) and global markets access (38\%) (UNCTAD, 2000).

Hence, the broad objective of this paper is to investigate the impact of financial development on the relationship between FDI and economic growth. The study differs from previous attempts in that it focuses on a relatively more homogenous region such as SSA rather than assume that the results based on global datasets reflect the peculiar characteristics of the vastly lower-income countries of SSA. The study also estimates threshold financial development levels essential for the expected FDI-economic growth effects.

While few studies have considered the relationship by focusing on Africa (Agbloyor et al., 2014), we conduct our study using a panel of 37 countries in SSA. We develop a conceptual framework based on the FDI photosynthesis model of Nguyen et al. (2009) and adapt it to 
reflect the role of the domestic financial system in intermediating the FDI-economic growth link.

The subsequent sections of the paper are organised as follows. Section 2 presents the methodology of the paper; Section 3 presents the estimation techniques; Section 4 discusses the data; Section 5 presents the estimation results; and lastly, Section 6 concludes the study as well as provides policy recommendations.

\section{METHODOLOGY}

We adapt the FDI photosynthesis model proposed by Nguyen et al. (2009) in developing a model of finance-based absorptive capacity and develop our econometric model. We construct a panel vector autoregressive (PVAR) model following Love and Zicchino (2006) in establishing the complementary relationship between finance and FDI, as well as adopt the econometric approach of Carkovic and Levine (2002) in showing the impact of domestic banking sector development on the FDI-economic growth relationship.

\section{Theoretical Framework: Photosynthesis Model of Finance-Based Absorptive Capacity}

The broad photosynthesis model developed by Nguyen et al. (2009) asserts that to assimilate the spillover benefits of FDI, the host country definitely needs to develop its absorptive capacities in physical infrastructure, human capital, technology, institutional development and domestic financial systems. Just as green plants require a comprehensive system of leaves, roots, stem and branches to absorb water and sunlight, the host country requires a comprehensive system of absorptive capacities to attract, spread and convert the benefits of FDI to economic growth.

Nguyen et al. (2009) note that the FDI spillovers can be transmitted to the host country via two levels: the macroeconomic (national) level and microeconomic (firm) level. The macroeconomic level entails the transfer of benefits to the host country through different channels. The first is technology, which is transferred through imitation, competition, and partnership with foreign firms; while the second is labour force through learning-by-doing, training and experience accumulation. At the microeconomic level, the local firm serves as a channel through which spillover benefits are transmitted through vertical and horizontal integration, training, skills acquisition, transfer of knowledge and labour turnover.

The foreign businesses can contribute to the national economy either directly through $100 \%$ ownership of businesses in the host country or by engaging in joint ventures with domestic firms. After the order of photosynthesis, the domestic firms are symbolized as the leaves of green plants for their role in the absorption process as they must possess the capacity to absorb the superior technology and knowledge diffused by the foreign firms (Nunnenkamp, 2004). We develop a conceptual framework that links the economic growth effect of FDI to the development of the domestic financial system as illustrated in Figure 2. 


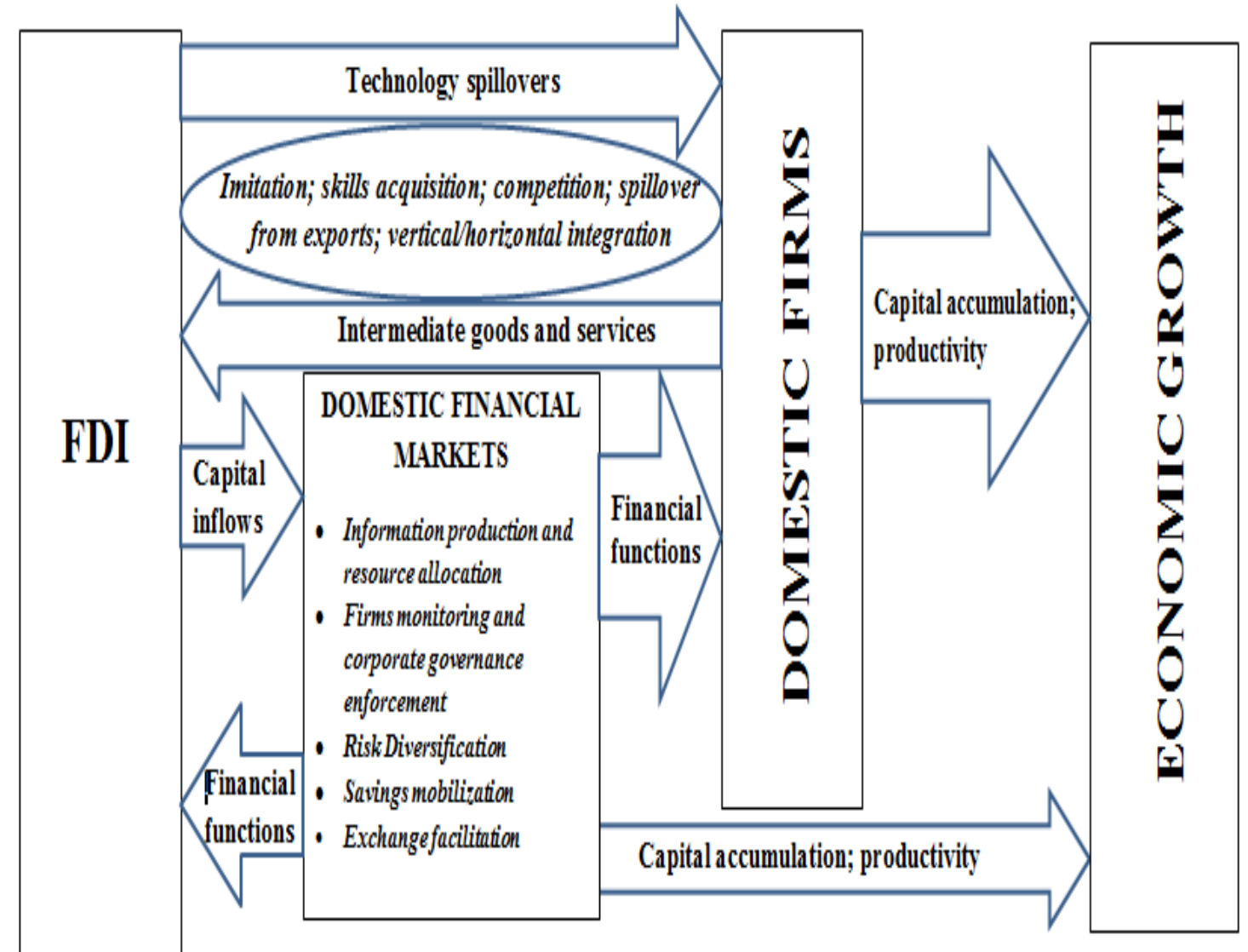

Figure 2: Financial Development and FDI Absorptive Capacity in the Host Country Source: Authors

The improvement of the core functions of the financial system highlighted in Figure 2 constitute financial development (Levine, 2005). Moreover, Financial development and FDI may be mutually beneficial in the sense that financial development can attract foreign firms by making the required financial services for their operations available while foreign firms can in turn, boost the availability of capital in the domestic financial system.

A positive causal effect running strictly from financial development to FDI, is an indication that the financial markets partially complement FDI activities. Moreover, a two-way positive causal relationship between financial development and FDI is an indication of a perfectly complementary relationship. The existence of either of these complementary relationships between finance and FDI is conceived as a basis for FDI to cause economic growth. Thus, we make the proposition that countries with better-developed financial systems have more capacity to absorb the benefits of FDI and transform the same to economic growth.

\section{Model Specification}

The model follows the framework of existing FDI-finance-economic growth literature such as Alfaro et al (2004) and Hermes and Lensink (2003), and so on. Thus, we have the following specification:

$$
Y_{i t}=A L_{i t}^{1-\alpha} K_{i t}^{\alpha}
$$

We subsume factors such as initial level of GDP per capita and financial development (environmental/ absorptive capacity factors) in $A$, population growth rate in $L$ and allow $K$ 
to capture the level of FDI. Subscripts $i$ and $t$ represent the country cross-sections and time, respectively.

As an opening approach, we examine the direct effect of FDI on the growth of the economy and conduct pooled OLS estimations using data averaged over the 25-year period 1989-2013 (as in Carkovic and Levine, 2002;) as follows:

$$
Y_{i t}=\beta_{0}+\beta_{1} \text { INITIAL GDP } P_{i t}+\beta_{2} X_{i t}+\beta_{3} Z_{i t}+\varepsilon_{i t}
$$

where $Y$ represents real per capita GDP growth rate, INITIAL GDP is specified as the initial level of the log of per capita GDP, $X$ is a vector of variables including population growth rate, the degree of trade openness, and of course, foreign direct investment (FDI). These variables have been described in literature as having robust effects on economic growth (King and Levine, 1993; Hermes and Lensink, 2003). $Z$ represents the list of some control variables that are used in cross-country growth literature, including government consumption, inflation rate, landlockedness, and measures of institutional quality such as democracy index and government effectiveness index, and the $\beta$ s are the coefficients to be estimated, where $\beta_{0}$ is the intercept of the model.

Next, we examine the FDI-growth relationship by investigating banking sector development as a channel through which FDI leads to economic growth. Thus, we create interactions between FDI and banking sector development variables [FDI (\% of GDP) $\times$ banking sector term] and test their significance by regressing economic growth rate on them as follows:

$$
Y_{i t}=\gamma_{0}+\gamma_{1} I_{N I T I A L G D P}+\gamma_{2} X_{i t}+\gamma_{3}\left(F D I_{i t} * \text { FINANCE }_{i t}\right)+\gamma_{4} Z_{i t}+\varepsilon_{i t}
$$

In equation 3 we implement the equation by interacting each of the banking sector development variables (FINANCE) with FDI separately and observe the coefficient estimates of the interaction term, i.e. $\gamma_{3}$. Also, FDI and banking sector development variables are included individually in the model in order to avoid a case whereby the interaction term proxies for either of the former variables (Alfaro et al., 2004).

Equations (2) and (3) are applicable for analysing both the direct effect of FDI on economic growth and the complementary effect of FDI and banking sector development on economic growth, respectively. Before considering the latter, i.e., the complementary effect of FDI and banking sector development, however, we first investigate the expected complementary relationship between FDI and banking sector development by exploring the causality links between the two variables. Thus, we specify a panel vector autoregression (PVAR) model which combines the conventional VAR methodology with the panel data method:

$$
\begin{aligned}
& F D I_{i t}=\phi_{1}+\sum_{k=1}^{\rho} \beta_{11, k} F D I_{t-k}+\sum_{k=1}^{\rho} \beta_{12, k} \operatorname{FINANCE}_{t-k}+u_{i}+e_{i t} \\
& \text { FINANCE }_{i t}=\phi_{2}+\sum_{k=1}^{\rho} \beta_{21, k} F D I_{t-k}+\sum_{k=1}^{\rho} \beta_{22, k} \text { FINANCE }_{t-k}+u_{j}+e_{j t}
\end{aligned}
$$


where $u_{i(j)}$ and $e_{i(j) t}$ represent panel fixed effects and idiosyncratic errors, respectively; $\beta_{\mathrm{ij}, \mathrm{k}}$ describes the effect of the $k$ th lagged value of variable $i(j)$ on the current value of variable $j(i)$. The VAR technique tells us the direction of Granger causality between financial development and FDI, and thus emphasizes the degree of complementarity between them.

\section{ESTIMATION TECHNIQUES}

In testing for the direct effect of FDI and subsequently, its interactive effect with finance on economic growth, we first adopt the panel ordinary least square (OLS) technique, which assumes that causality flows directly from the independent variables to the dependent variable. However, endogeneity concerns often arise in growth regressions, and the heterogeneous nature of panel data may constrain the adequacy of OLS. Thus, we address these issues by running fixed/random effect as well as Generalized Method of Moment (GMM) regressions. Breusch-Pagan Lagrange Multiplier (LM) test is used to clarify the adequacy of the OLS model. By principle, a high value of LM would favour the fixed/random effects model over the pooled model ( $\mathrm{Li}$ and Liu, 2005). Based on the Hausman (1978) test, a choice is made between the fixed effects and random effects models. ${ }^{1}$ Next, the study adopts the GMM approach developed for dynamic panel data, which explores the time-series along with the cross-country dimensions of the data. The basic method developed by Arellano and Bond (1991) makes use of internal instruments. Following Carkovic and Levine (2002), we average data over non-overlapping three-year periods so as to address business-cycle effects ${ }^{2}$ and consider the following sequence of equations:

$$
y_{i t}-y_{i, t-1}=(\alpha-1) y_{i, t-1}+\beta^{\prime} X_{i t}+\eta_{i}+\varepsilon_{i t}
$$

In equation (6), $y$ represents the growth rate of real per capita GDP; $X$ represents the set of explanatory variables, i.e., FDI, financial development, and the interaction term, and other possible determinants of growth; $\eta$ represents an unobserved country-specific effect, $\varepsilon$ is the error term, and the subscripts $i$ and $t$ represent country and time period, respectively. The goal is to consistently estimate parameters when $\eta_{i}$ is a fixed effect. However, the estimators are also consistent if $\eta_{i}$ is a random effect (Cameron and Trivedi, 2009). We can rewrite equation (6) thus:

$$
y_{i t}=\alpha y_{i, t-1}+\beta^{\prime} X_{i t}+\eta_{i}+\varepsilon_{i t}
$$

Taking first differences of equation (7) in order to expunge the prospective biases related with unobserved fixed/random, country effects:

$$
\Delta y_{i t}=\alpha \Delta y_{i, t-1}+\beta^{\prime} \Delta X_{i t}+\Delta \varepsilon_{i t}
$$

However, there is a problem - the new error term $\Delta \varepsilon_{i t}$ is correlated with the new lagged dependent variable $\Delta y_{i, t-1}$ - and this necessitates the use of instruments to deal with the

\footnotetext{
1 The null hypothesis of the Hausman test is that the unobserved effects are not correlated with the observed regressors, hence the consistency of both FE and RE estimators as they should yield alike coefficients. The alternative hypothesis is that the unobserved effects are correlated with the observed regressors, thus, only the FE estimator is consistent.

2 Carkovic and Levine (2002) make use of five-year averages.
} 
resulting endogeneity. Therefore, assuming non-serial correlation of the error term and weak exogeneity (i.e. the non-correlation of the explanatory variables with future values of the error term), the GMM dynamic panel estimator makes use of the following moment conditions:

$$
\begin{array}{cc}
E\left[y_{i, t-s} \cdot\left(\Delta \varepsilon_{i t}\right)\right]=0 & \text { for } s \geq 2 ; t=3, \ldots, T \\
E\left[X_{i, t-s} .\left(\Delta \varepsilon_{i t}\right)\right]=0 & \text { for } s \geq 2 ; t=3, \ldots, T
\end{array}
$$

where $s$ and $t$ indicate the three-year period under assessment. The estimator obtained under this condition is known as the difference estimator. However, lagged levels make weak instruments for regression equation in first differences when the explanatory variables are persistent over time. This influences the asymptotic and small-sample performance of the difference estimator, thus resulting in asymptotic increments in the variance of coefficients, and bias of coefficients. To address this, we use an estimator that combines the regression in differences with the regression in levels (i.e., the system GMM), where the instruments for the regression in levels are the lagged differences of the corresponding variables (Arellano and Bover, 1995; Blundell and Bond, 1998). The validity of this procedure however, depends on this additional assumption: although there may be correlation between the right-hand variables and the country-specific effect in equation (7), this correlation does not exist between the differences of these variables and the country-specific effect. Other moment conditions assumed in Carkovic and Levine (2002) are applicable.

The instruments used for our analysis have to be valid so as to ensure the consistency of the GMM estimator. Thus, we carry out two specification tests. The first is the Sargan test of overidentifying restrictions, and the second is the test for non-serial correlation of the error term $\varepsilon_{i t}$ . The first tests the overall validity of the instruments by analysing the moment conditions used in estimating the model, while the second examines the second-order serial correlation of the differenced error term in both the difference and system difference-level regressions. To implement these GMM regressions, the study uses the xtabond2.ado program developed by Roodman (2009). Under this technique, we use the two-step GMM estimator based on the assumption that it is superior to the one-step estimator in terms of efficiency. The xtabond2 regressions report the Sargan overidentifying restrictions and the second-order serial correlation tests.

To implement the PVAR model to test the complementarity between financial development and FDI, we employ the pvar package of programs developed by Abrigo and Love (2015), following the work of Holtz-Eakin, Newey and Rosen (1988). The PVAR model is based on the system GMM methodology and therefore allows for individual heterogeneity. To avoid the problem of biased coefficients (due to correlation of regressors with fixed effects arising from lagged dependent variables) created by the mean-differencing process, the 'Helmert procedure', which involves forward-differencing is applied. ${ }^{3}$ Thus, the orthogonality between the transformed and lagged variables that are used as instruments is preserved. The VAR analysis is based on the choice of optimal lag order in the PVAR specifications and moment conditions. Post-estimation Granger causality test, overidentifying restrictions and secondorder serial correlation tests, as well as the unit circle tests for stability of panel VAR estimates, are performed to substantiate these regressions.

3 See Arellano and Bover, 1995. 


\section{DATA DESCRIPTIONS AND SOURCES}

The study makes use of panel data consisting of 37 SSA countries from 1989-2013. The countries analysed are listed in Table 1 . The data includes the annual measures of economic growth, FDI, financial development, and a series of control variables, most of which are widely included in standard growth regressions.

Table 1: List of Selected SSA Countries

\begin{tabular}{|c|c|c|c|}
\hline Angola ${ }^{a}$ & Cote d'Ivoire ${ }^{a}$ & Mauritius ${ }^{a}$ & Togo $^{b}$ \\
\hline Benin $^{b}$ & Ethiopiab $^{\mathrm{b}}$ & Mozambiqueb & Ugandab \\
\hline Botswana ${ }^{a}$ & Gabona & Namibiaa & Zambia ${ }^{a}$ \\
\hline Burkina Fasob & Gambiab & Nigerb & Zimbabweb \\
\hline Burundib & Ghana $^{\mathrm{a}}$ & Nigeriaa & \\
\hline Cameroona & Guineab $^{b}$ & Senegala & \\
\hline Central African Republicb & Kenyaa $^{a}$ & Seychelles ${ }^{a}$ & \\
\hline Chadb & Lesotho $^{\mathrm{a}}$ & South Africa ${ }^{a}$ & \\
\hline Comoros $^{b}$ & Madagascarb & Sudana & \\
\hline Congo Dem. Republicb & Malawib & Swazilanda & \\
\hline Congo Republic ${ }^{a}$ & Malib & Tanzaniab & \\
\hline
\end{tabular}

Note: a indicates middle-income country while b indicates low-income country based on World Bank (2015) classifications.

The growth rate of output is measured as growth rate of per capita real GDP. FDI net inflows as percentage of GDP are used to indicate the level of FDI. We use two measures of financial development, which focus on the banking sector. They include money and quasi money (M2) as percentage of GDP and credit offered by financial intermediaries or the banking sector to the private sector as a ratio of GDP (private credit). Given the observed shortcomings of M2, which measures the degree of monetization (Fama, 1980; King and Levine, 1993; Levine, Loayza and Beck, 2000), private credit serves as an alternative measure. Unlike other measures of financial development, it focuses mainly on the private sector, thus distinguishing the private sector from the other end users of financial intermediary credits, that is, the public sector (King and Levine, 1993; Alfaro et al., 2004). Moreover, it is private credit which indicates the extent to which banks are directing society's savings to productive uses (Honohan and Beck, 2007).

Other variables employed in the study include the level of per capita GDP; population growth rate, which is measured as the first difference of the log of population; the annual rate of inflation based on the consumer price index (CPI), which proxies for macroeconomic stability; trade (exports plus imports) as percentage of GDP, which is a measure of openness to international trade; and general government final consumption expenditure as percentage of GDP, which is a measure of government size. We include indexes such as democracy index and government effectiveness index, which capture the levels of political and institutional quality. Also, a measure of geographical location, the dummy variable for landlockedness is included, following recent growth literature, which emphasizes the direct effect of geography on economic growth (Acemoglu, Jackson \& Robinson, 2003; Redding \& Venables, 2004; Adams, 2009).

Except for landlockedness, democracy index and government effectiveness index, all variables are sourced from the World Development Indicators (WDI) of the World Bank (2015).

Democracy index is obtained from the Polity IV dataset version of the Center for Systemic Peace (CSP, 2014). The index is an additive eleven-point scale (0-10), derived from codings of the competitiveness of political participation, the openness and competitiveness of executive recruitment, and constraints on the chief executive. The country is considered as having higher 
institutional quality the higher its score in the index.

Government effectiveness index is obtained from the Worldwide Governance Indicators (WGI) of the World Bank (2014). According to Kaufmann, Kraay and Mastruzzi (2010) who constructed the index, government effectiveness "reflects perceptions of the quality of public services, the quality of the civil service and the degree of its independence from political pressures, the quality of policy formulation and implementation, and the credibility of the government's commitment to such policies". The index ranges from approximately -2.5 to 2.5 (i.e., weak to strong government effectiveness, respectively). However, the index is only available over the period 1996-2013.

The dummy for geography is created by assigning 1 to landlocked countries and 0 elsewhere.

\section{ESTIMATION RESULTS}

The study examines whether the growth effects of FDI are dependent on the development of the domestic financial system - the banking sector in particular - in SSA. First, we examine the independent effect of FDI on economic growth. Before examining the role of finance in the FDIeconomic growth relationship, we consider the causal relationship between banking sector development and FDI under the premise that a causal relationship between the two is crucial to their complementary effect on growth. The growth regressions control for initial income, endogeneity, heterogeneity and other determinants of growth.

\section{The Direct Effect of FDI on Economic Growth}

To examine the direct effect of FDI on economic growth, Table 2 presents the results of OLS and panel models comprising of the fixed effect ${ }^{4}$ estimates and the dynamic panel regressions, which include the difference GMM and the system GMM estimates. In the OLS and fixed effect regressions, we begin with models comprising of initial GDP per capita, population, inflation, government consumption, and trade openness in regression 1 . The conditioning set of variables is expanded with one variable at a time by government effectiveness (an institutional variable) in regression 2 and a financial development variable (private credit) in regression 3. The GMM regressions satisfy the required post-estimation tests such as the Sargan test of overidentifying restriction and test for second-order serial correlation.

\footnotetext{
${ }^{4}$ The fixed effects model is adjudged superior to the OLS and random effects specifications based on Breusch and Pagan, and Hausman tests, respectively.
} 
Table 2: The Direct Effect of FDI on Economic Growth

Dependent variable: Growth rate of per capita GDP

\begin{tabular}{|c|c|c|c|c|c|c|c|c|}
\hline \multirow[b]{2}{*}{$\begin{array}{l}\text { Conditioning information } \\
\text { set }\end{array}$} & \multicolumn{2}{|c|}{1} & \multicolumn{2}{|c|}{2} & \multicolumn{2}{|c|}{3} & 4 & 5 \\
\hline & OLS & $\mathrm{FE}$ & OLS & $\mathrm{FE}$ & OLS & $\mathrm{FE}$ & $\begin{array}{l}\text { DIFF } \\
\text { GMM }\end{array}$ & $\begin{array}{l}\text { SYS } \\
\text { GMM }\end{array}$ \\
\hline Constant & $\begin{array}{l}4.83^{* *} \\
(2.00)\end{array}$ & $\begin{array}{l}2.41 \\
(1.19)\end{array}$ & $\begin{array}{l}5.89^{* *} \\
(2.41)\end{array}$ & $\begin{array}{l}2.72 \\
(1.29)\end{array}$ & $\begin{array}{l}4.47^{*} \\
(1.81)\end{array}$ & $\begin{array}{l}3.29 \\
(1.32)\end{array}$ & - & $\begin{array}{l}26.45 \\
(1.02)\end{array}$ \\
\hline Initial income per capita & $\begin{array}{l}-0.400 \\
(-1.96)\end{array}$ & $\begin{array}{l}- \\
-\end{array}$ & $\begin{array}{l}-0.66^{* * *} \\
(-2.92)\end{array}$ & $\begin{array}{l}- \\
-\end{array}$ & $\begin{array}{l}-0.55^{* *} \\
(-2.44)\end{array}$ & $\begin{array}{l}- \\
-\end{array}$ & $\begin{array}{l}- \\
-\end{array}$ & $\begin{array}{l}-0.56 \\
(-0.14)\end{array}$ \\
\hline Population & $\begin{array}{l}-15.25 \\
(-1.05)\end{array}$ & $\begin{array}{l}8.03 \\
(0.51)\end{array}$ & $\begin{array}{l}5.90 \\
(0.41)\end{array}$ & $\begin{array}{l}4.89 \\
(0.29)\end{array}$ & $\begin{array}{l}10.37 \\
(0.66)\end{array}$ & $\begin{array}{l}1.98 \\
(0.11)\end{array}$ & $\begin{array}{l}539 \\
(1.95)\end{array}$ & $\begin{array}{l}-164.88 \\
(-0.66)\end{array}$ \\
\hline Inflation & $\begin{array}{l}-0.00^{* * *} \\
(-8.19)\end{array}$ & $\begin{array}{l}-0.00^{* * *} \\
(-5.31)\end{array}$ & $\begin{array}{l}-0.01^{* * *} \\
(-2.88)\end{array}$ & $\begin{array}{l}-0.02^{* * *} \\
(-5.01)\end{array}$ & $\begin{array}{l}- \\
0.01 * * * \\
(-0.11)\end{array}$ & $\begin{array}{l}-0.02^{* * *} \\
(-5.12)\end{array}$ & $\begin{array}{l}-0.03 \\
(-0.96)\end{array}$ & $\begin{array}{l}0.04 \\
(0.47)\end{array}$ \\
\hline $\begin{array}{l}\text { Government } \\
\text { Consumption }\end{array}$ & $\begin{array}{l}-0.05 \\
(-1.21)\end{array}$ & $\begin{array}{l}-0.30 * * * \\
(-3.59)\end{array}$ & $\begin{array}{l}-0.02 \\
(-0.61)\end{array}$ & $\begin{array}{l}-0.134 \\
(-2.17)\end{array}$ & $\begin{array}{l}-0.02 \\
(-0.49)\end{array}$ & $\begin{array}{l}-0.12^{*} \\
(-1.94)\end{array}$ & $\begin{array}{l}-0.54 \\
(-1.24)\end{array}$ & $\begin{array}{l}-1.31^{* * *} \\
(-2.65)\end{array}$ \\
\hline Trade openness & $\begin{array}{l}0.01 \\
(1.50)\end{array}$ & $\begin{array}{l}0.04^{* * *} \\
(2.75)\end{array}$ & $\begin{array}{l}0.01^{*} \\
(1.74)\end{array}$ & $\begin{array}{l}0.04^{* * *} \\
(2.89)\end{array}$ & $\begin{array}{l}0.01 \\
(1.61)\end{array}$ & $\begin{array}{l}0.04^{* * *} \\
(2.84)\end{array}$ & $\begin{array}{l}0.11 \\
(1.67)\end{array}$ & $\begin{array}{l}0.08 \\
(1.20)\end{array}$ \\
\hline $\begin{array}{l}\text { Government } \\
\text { effectiveness }\end{array}$ & - & - & $\begin{array}{l}1.27^{* * *} \\
(3.54)\end{array}$ & $\begin{array}{l}3.14^{* * *} \\
(2.97)\end{array}$ & $\begin{array}{l}1.26^{* * *} \\
(3.16)\end{array}$ & $\begin{array}{l}3.20^{* * *} \\
(3.83)\end{array}$ & $\begin{array}{l}-7.49 \\
(-0.81)\end{array}$ & $\begin{array}{l}4.72 \\
(1.30)\end{array}$ \\
\hline Financial Development & - & $\begin{array}{l}- \\
-\end{array}$ & $\begin{array}{l}- \\
-\end{array}$ & - & $\begin{array}{l}0.00 \\
(0.02)\end{array}$ & $\begin{array}{l}-0.03 \\
(-1.20)\end{array}$ & $\begin{array}{l}-0.201 \\
(-1.00)\end{array}$ & $\begin{array}{l}-0.01 \\
(-0.08)\end{array}$ \\
\hline FDI & $\begin{array}{l}0.08^{* *} \\
(2.46)\end{array}$ & $\begin{array}{l}0.08^{* *} \\
(2.43)\end{array}$ & $\begin{array}{l}0.05 \\
(1.44)\end{array}$ & $\begin{array}{l}0.04 \\
(1.29)\end{array}$ & $\begin{array}{l}0.05 \\
(1.64)\end{array}$ & $\begin{array}{l}0.04 \\
(1.43)\end{array}$ & $\begin{array}{l}-0.27 \\
(-1.37)\end{array}$ & $\begin{array}{l}0.07 \\
(0.37)\end{array}$ \\
\hline Number of groups & 1 & 37 & 1 & 37 & 1 & 36 & 35 & 36 \\
\hline $\begin{array}{l}\text { Number of observations }{ }^{1} \\
\mathrm{R}^{2} \text { (adjusted) }\end{array}$ & $\begin{array}{l}265 \\
0.15\end{array}$ & $\begin{array}{l}265 \\
0.30\end{array}$ & $\begin{array}{l}232 \\
0.12\end{array}$ & $\begin{array}{l}232 \\
0.32\end{array}$ & $\begin{array}{l}227 \\
0.13\end{array}$ & $\begin{array}{l}227 \\
0.30\end{array}$ & 190 & 227 \\
\hline $\begin{array}{l}\text { Prob > F } \\
\text { Serial correlation test (p- } \\
\text { value) } \\
\text { Sargan test (p-value) }\end{array}$ & 0.00 & 0.00 & 0.00 & 0.00 & 0.00 & 0.00 & $\begin{array}{l}0.04 \\
0.229 \\
0.756\end{array}$ & $\begin{array}{l}0.01 \\
0.891 \\
0.671\end{array}$ \\
\hline
\end{tabular}

Notes: Heteroskedasticity-adjusted t-values for the OLS and fixed effects regressions and z-values for the dynamic panel regressions are reported below estimated coefficient values. ${ }^{* * *}$, ${ }^{* *}$ and ${ }^{*}$ indicate significance at $1 \%, 5 \%$ and $10 \%$, respectively. The null hypothesis of the serial correlation test is that the errors in the first difference regression exhibit no second-order autocorrelation, while the null hypothesis of the Sargan test is that the overidentifying restrictions are valid.

1Panel estimations use 3-year periods.

FDI has a positive and significant coefficient in the first regression but becomes insignificant in the rest of the regressions as other variables are introduced into the model. In the OLS regressions, initial income enters significantly with the expected negative sign found in many cross-country regressions, thereby suggesting economic convergence in the sample of SSA countries. Population growth rate has no significant effect on economic growth in any of the regressions while inflation is shown to have negative and significant effect on the growth rate of SSA in all the OLS and fixed effect regressions. While government consumption is shown to have negative effect in all the regressions, trade openness is shown to have a positive and significant effect in all the fixed effect regressions. The relevance of good governance for SSA is emphasized in the regressions as government effectiveness enters with a positive sign and high significance in both OLS and fixed effect regressions. Financial development is not significant in the OLS and fixed effect regressions.

Given the shortcomings associated with the OLS and fixed effect models as earlier discussed, 
we run the difference and system GMM regressions presented in regressions 4 and 5, respectively. ${ }^{5}$ Again, FDI is shown to lack a direct positive impact on economic growth of SSA. It enters the difference GMM regression with a negative sign and the system GMM with a positive sign, insignificantly in both cases, thus supporting previous notable studies such as Carkovic and Levine (2002); Alfaro et al. (2004); and Agbloyor et al. (2014), that FDI does not exert direct or independent positive impacts on economic growth.

Throughout the analysis, the system GMM regressions are generally preferred to the difference GMM ones. This is because system GMM makes use of lagged differences, which are stronger instruments as against difference GMM, which makes use of lagged level instruments that are weaker (Söderbom, Teal, Eberhardt, Quinn and Zeitlin, 2015). Hence, from regression 5, other determinants of economic growth are reported as follows.

There is a negative but insignificant sign on the log of initial GDP. This may not be surprising as it could be an indication that the richer countries of SSA tend to achieve faster growth rates compared to the poorer ones over the period of study, thus indicating a lack of conformity with the convergence hypothesis. Population growth has a negative but insignificant effect on economic growth, inflation has an insignificant effect on economic growth, while government consumption has a negative effect on growth, which is highly significant (at 1\%). Trade openness also has a positive effect on economic growth, even though not significant as observed in the fixed effect regressions. Government effectiveness has a high coefficient, although it is not significant as observed in the OLS and fixed effect regressions. Finally, private credit, which is the financial development variable enters both the difference and system GMM regressions negatively and insignificantly. ${ }^{6}$ This shows that the banking sector in SSA does not directly promote economic growth in the region.

Ultimately, both the difference and system GMM models reject the hypothesis that FDI has a positive and significant effect on the economic growth of SSA when considered independently. This result suggests the need to investigate the conditions under which FDI would have a positive and empirically significant effect on the economic growth of the region.

\section{Causal Relationship between Financial Development and FDI}

In line with the broad objective to establish the role of financial development in mediating the effect of FDI on economic growth in SSA, it is important to clarify whether complementarities exist between financial development and FDI. To achieve this, the nature of Granger causality between financial development and FDI is investigated. The existence of causal relationship between the two variables, especially one running from financial development to FDI, may be an indication that the domestic financial system provides some absorptive capacity crucial to transforming the growth effect of FDI to a positive and significant one in the host country.

In addition to the general consideration of the relationship between financial development and FDI in the sample of 37 SSA countries, the sample is separated based on income classes so as to compare the financial development-FDI relationship across income categories, viz., the lowincome group and the middle-income group. Analysing the sample based on the income groups follows from earlier findings that middle-income countries generally have more developed financial systems than low-income countries (Roe, 2016). As earlier stated, the Granger

5 The serial correlation and Sargan tests confirm the validity of these regressions.

${ }^{6} \mathrm{~A}$ similar effect as that of private credit is obtained when M2 is introduced as the financial development variable. 
causality analysis is based on a VAR model which is estimated by system GMM. We adopt the 'Helmert procedure' which ensures that the country-time and fixed effects inherent in the variables are removed prior to estimation following Love and Zicchino (2006).

Both financial development variables and FDI are scaled by measuring them as a percentage of GDP. Tables 3 and 4 present the regressions based on the banking sector development variables, i.e., private credit and M2. Based on the lag selection tests, the VAR regressions are performed using one lag. All the regressions are validated by the post-estimation tests such as the Hansen (Sargan) test of overidentifying restriction and the unit circle. ${ }^{7}$

In Table 3, Panel A shows the causal relationship between private credit and FDI in the full SSA sample of 37 countries. The estimates show that while private credit positively Granger-causes FDI at the 1\% significance level, FDI has a positive but insignificant effect on private credit in the full sample. For the sub-sample of middle-income countries as shown in Panel B, private credit has a positive effect on FDI, which is only significant at $10 \%$ while FDI has a negative but insignificant causal effect on financial development. Panel C containing the sub-sample of lowincome countries shows that both financial development and FDI positively Granger-cause each other at $5 \%$ maximum. Thus, while a positive but weak one-way causality runs from private credit to FDI in the middle-income countries, there is a positive bi-causal relationship between the two variables in the low-income countries. Overall however, there exists a oneway causal effect from private credit to FDI in the SSA region. It can also be observed that the effect of private credit on FDI is higher in the low-income countries than in the middle-income and full samples, given their coefficient values. 
Table 3: Causal Relationship between Financial Development and FDI (Private Credit)

\begin{tabular}{|c|c|c|}
\hline \multirow[t]{2}{*}{ Dependent variable } & \multicolumn{2}{|c|}{ Estimated coefficient of lagged explanatory variable } \\
\hline & $P R I V_{t-1}$ & $F D I_{t-1}$ \\
\hline \multicolumn{3}{|l|}{ Panel A: Full SSA sample } \\
\hline$F D I_{t}$ & $0.068(2.95)^{* * *}$ & $0.684(9.53)^{* * *}$ \\
\hline$P R I V_{t}$ & $0.921(28.22)^{* * *}$ & $0.003(0.14)$ \\
\hline $\begin{array}{l}\text { Number of countries } \\
\text { Number of observations } \\
\text { Hansen's J statistic }\end{array}$ & \multicolumn{2}{|l|}{$\begin{array}{l}37 \\
814 \\
14.30(0.282)\end{array}$} \\
\hline \multicolumn{3}{|c|}{ Panel B: Middle-income subgroup } \\
\hline$F D I_{t}$ & $0.060(1.94)^{*}$ & $0.601(6.73)^{* * *}$ \\
\hline$P R I V_{t}$ & $0.915(24.49)^{* * *}$ & $-0.039(-1.42)$ \\
\hline $\begin{array}{l}\text { Number of countries } \\
\text { Number of observations } \\
\text { Hansen's J statistic }\end{array}$ & \multicolumn{2}{|l|}{$\begin{array}{l}18 \\
405 \\
12.53(0.404)\end{array}$} \\
\hline \multicolumn{3}{|c|}{ Panel C: Low-income subgroup } \\
\hline$F D I_{t}$ & $0.104(4.84)^{* * *}$ & $0.790(8.93)^{* * *}$ \\
\hline$P R I V_{t}$ & $0.876(28.06)^{* * *}$ & $0.085(2.28)^{* *}$ \\
\hline $\begin{array}{l}\text { Number of countries } \\
\text { Number of observations } \\
\text { Hansen's J statistic }\end{array}$ & \multicolumn{2}{|l|}{\begin{tabular}{|l|}
19 \\
409 \\
$18.36(0.105)$ \\
\end{tabular}} \\
\hline
\end{tabular}

Notes: The 1 lag VAR model is estimated by GMM, country-time and fixed effects are removed prior to estimation. Panels are classified into middle-income and low-income subgroups based on World Bank classifications in WDI. Heteroskedasticity-adjusted z-statistics are reported in parentheses. ${ }^{* *},{ }^{* *}$, and ${ }^{*}$ indicate significance at $1 \%, 5 \%$, and $10 \%$, respectively. Hansen's J chisquared statistics of overidentifying restriction are reported with corresponding p-values in parenthesis. The null hypothesis of the overidentifying restrictions test is that the overidentifying restrictions are valid. FDI indicates Foreign Direct Investment while PRIV indicates the private credit variable.

In Table 4, the causal relationship between M2 and FDI is presented. Panel A of the table shows that M2 positively Granger-causes FDI at 5\% significance level but FDI has a negative but insignificant effect on M2 in the full SSA sample. In the sub-sample of middle-income countries given in Panel B, M2 has a positive but insignificant effect on FDI while FDI has a negative but insignificant effect on M2. For the sub-sample of low-income countries given in Panel C, there exists a positive and significant bi-causal relationship between M2 and FDI at 5\% maximum. Thus, while no significant relationship is observed between M2 and FDI in middle-income countries, there exists a positive and significant two-way causal relationship between the two variables in the low-income panel of countries. Generally, as observed for private credit, there is a one-way positive causal effect running from M2 to FDI in SSA. 
Table 4: Causal Relationship between Financial Development and FDI (M2)

\begin{tabular}{|c|c|c|}
\hline \multirow[t]{2}{*}{ Dependent variable } & \multicolumn{2}{|c|}{ Estimated coefficient of lagged explanatory variable } \\
\hline & $M 2_{t-1}$ & $F D I_{t-1}$ \\
\hline \multicolumn{3}{|l|}{ Panel A: Full SSA sample } \\
\hline$F D I_{t}$ & $0.028(2.19)^{* *}$ & $0.681(9.27)^{* * *}$ \\
\hline$M 2_{t}$ & $0.993(22.83)^{* * *}$ & $-0.011(-0.29)$ \\
\hline $\begin{array}{l}\text { Number of countries } \\
\text { Number of observations } \\
\text { Hansen's J statistic }\end{array}$ & \multicolumn{2}{|l|}{$\begin{array}{l}37 \\
814 \\
14.08(0.296)\end{array}$} \\
\hline \multicolumn{3}{|c|}{ Panel B: Middle-income subgroup } \\
\hline$F D I_{t}$ & $0.029(1.50)$ & $0.568(6.39)^{* * *}$ \\
\hline$M 2_{t}$ & $0.943(25.00)^{* * *}$ & $-0.053(-1.39)$ \\
\hline $\begin{array}{l}\text { Number of countries } \\
\text { Number of observations } \\
\text { Hansen's J statistic }\end{array}$ & \multicolumn{2}{|l|}{$\begin{array}{l}18 \\
405 \\
9.66(0.646)\end{array}$} \\
\hline \multicolumn{3}{|c|}{ Panel C: Low-income subgroup } \\
\hline$F D I_{t}$ & $0.025(3.63)^{* * *}$ & $0.925(18.02)^{* * *}$ \\
\hline$M 2_{t}$ & $0.856(16.41)^{* * *}$ & $0.305(4.38)^{* *}$ \\
\hline $\begin{array}{l}\text { Number of countries } \\
\text { Number of observations } \\
\text { Hansen's J statistic }\end{array}$ & \multicolumn{2}{|l|}{\begin{tabular}{|l|}
19 \\
409 \\
$34.66(0.532)$ \\
\end{tabular}} \\
\hline
\end{tabular}

Notes: The 1 lag VAR model is estimated by GMM, country-time and fixed effects are removed prior to estimation. Panels are classified into middle-income and low-income subgroups based on World Bank classifications in WDI. Heteroskedasticity-adjusted z-statistics are reported in parentheses. ${ }^{* * *}, * *$, and $*$ indicate significance at $1 \%, 5 \%$, and $10 \%$, respectively. Hansen's J chisquared statistics of overidentifying restriction are reported with corresponding p-values in parenthesis. The null hypothesis of the overidentifying restrictions test is that the overidentifying restrictions are valid. FDI indicates Foreign Direct Investment while M2 indicates the monetization variable.

The strong causal relationship between banking sector development and FDI in the lowincome sub-sample compared to the middle-income sub-sample supports earlier theoretical work in which financial development is shown to reduce financial constraints, thereby, having beneficial impacts on investment. In this regard, the less financially developed countries have relatively greater investment sensitivity to improvements in financial access (Hubbard, 1998). Our present study in which FDI responds with a relatively higher intensity to private credit (with a coefficient value of 0.104 ) in low-income countries of SSA than in the middle-income countries of the region (with 0.060 coefficient value), is consistent with this theorized pattern of finance-investment relationship. This underscores the implication of credit constraints to the private sector and supports the empirical evidence in which the effect of financial development on investment is found to indicate the severity of financing constraints, and is significantly larger in countries with less financially developed systems (Love, 2003; Love and Zicchino; 2006)

It is also observed that the effect of private credit on FDI in the full SSA sample is stronger than that of M2 as private credit has a coefficient of 0.068 compared to M2 which has a coefficient of 0.028. This underscores that an efficient allocation of credits may have more beneficial impact on private investments than broad supply of money, which may not necessarily translate into efficient allocation to the financially deficient sectors. 
As regards the effect of FDI on banking sector development, the former doesn't seem to promote the latter in middle-income countries, whereas, the banking sector in the low-income countries benefit from the increased flow of foreign capital brought into the countries. FDI could improve financial intermediation in the poorer (low-income) countries by creating additional liquidity as well as making available more credit for financial intermediation. In the middle-income countries however, it could be that foreign businesses prefer to borrow from rather than make savings deposits in the local banks.

\section{The Domestic Financial System and the FDI-Economic Growth Relationship}

The achievement of a causal relationship, at least in a unidirectional form running from banking sector development indicators to FDI in the preceding section, is an indication that even though FDI does not directly cause economic growth in SSA, banking sector development may significantly complement the flow of foreign investments into the region. Essentially, one can expect the insignificant independent effect of FDI on economic growth observed in the study to be reversed, given the FDI absorptive capacity induced by the domestic banking sector. Thus, we investigate the effect of banking sector development on the relationship between FDI and economic growth. The democracy index and dummy variable for landlockedness are included in the regressions to increase the efficiency of the model.

Assessing the interaction effect of FDI and each of the financial development variables allows us to determine the relative effects of private credit and money supply on the FDI-economic growth relationship as well as determine the threshold levels of banking sector development essential for enhancing the positive effect of FDI on economic growth in SSA as a whole. Tables 5 and 6 contain the results of the regressions assessing the financial development channels through which FDI affects economic growth. As in Table 2, which presents the direct effect of FDI on SSA's economic growth, each of the Tables contain the pooled OLS, fixed effects, difference GMM, and system GMM regressions as contained in the columns for regressions 1 to 4 , respectively. Each financial development channel is explored in separate regressions in order to avoid multicollinearity. Emphasis is placed on the interaction terms of FDI and the respective banking sector development variables rather than the individual coefficients of FDI and banking sector development. This is because the interaction term captures an important allocation function of the financial institutions, indicating that financial development is a means to an end, rather than an end in itself (Alfaro et al., 2004). Also, for reasons earlier discussed, the system GMM regression results are preferred to the other regressions. The Sargan and second-order serial correlation tests generally support the various specifications of the difference and system GMM models.

\section{Private credit channel}

Table 5 assesses whether the level of domestic credit to private sector by banks (private credit) enhances the FDI-growth relationship in SSA. The OLS and fixed effect regressions show that the interaction term of FDI and private credit yields positive estimates, which are very low and statistically insignificant. The difference GMM model regression also yields a positive coefficient of 0.036 for the interaction, which is significant at the $10 \%$ level. However, our most preferred model, the system GMM yields a higher coefficient of 0.061 , which is highly significant at the $1 \%$ level. In essence, the results show that increasing the levels of domestic credit to the private sector enhances the effect of FDI on economic growth in SSA. 
Table 5: The Complementary Effect of Banking Sector Development and FDI (Private Credit Channel)

Dependent variable: Growth rate of per capita GDP

\begin{tabular}{|c|c|c|c|c|}
\hline Conditioning information set & $\begin{array}{c}1 \\
\text { OLS }\end{array}$ & $\begin{array}{c}2 \\
\mathrm{FE}\end{array}$ & $\begin{array}{c}3 \\
\text { DIFF GMM }\end{array}$ & $\begin{array}{c}4 \\
\text { SYS GMM }\end{array}$ \\
\hline Constant & $\begin{array}{l}3.265 \\
(1.27)\end{array}$ & $\begin{array}{c}-48.102^{* *} \\
(-2.42)\end{array}$ & - & $\begin{array}{l}40.436 \\
(0.67)\end{array}$ \\
\hline Initial income per capita & $\begin{array}{c}-0.459^{*} \\
(-1.81)\end{array}$ & - & - & $\begin{array}{l}-4.279 \\
(-0.54)\end{array}$ \\
\hline Population & $\begin{array}{l}61.960 \\
(1.34)\end{array}$ & $\begin{array}{c}3.27^{* * *} \\
(2.58)\end{array}$ & $\begin{array}{c}500.303 \\
(1.54)\end{array}$ & $\begin{array}{c}278.575 \\
(0.88)\end{array}$ \\
\hline Government consumption & $\begin{array}{l}-0.025 \\
(-0.76)\end{array}$ & $\begin{array}{c}-0.167^{* * *} \\
(-2.75)\end{array}$ & $\begin{array}{l}-0.622 \\
(-1.28)\end{array}$ & $\begin{array}{l}-1.028 \\
(-0.91)\end{array}$ \\
\hline Trade openness & $\begin{array}{l}0.016^{*} \\
(1.94)\end{array}$ & $\begin{array}{c}0.045^{* *} \\
(2.53)\end{array}$ & $\begin{array}{l}0.108 \\
(1.15)\end{array}$ & $\begin{array}{c}0.166^{* *} \\
(2.15)\end{array}$ \\
\hline Democracy & $\begin{array}{c}0.032^{* * *} \\
(3.25)\end{array}$ & $\begin{array}{c}0.040^{* * *} \\
(2.97)\end{array}$ & $\begin{array}{l}0.015 \\
(0.16)\end{array}$ & $\begin{array}{l}-0.037 \\
(-0.60)\end{array}$ \\
\hline Government effectiveness & $\begin{array}{c}1.215^{* * *} \\
(2.94)\end{array}$ & $\begin{array}{c}3.306^{* * *} \\
(3.34)\end{array}$ & $\begin{array}{l}-4.187 \\
(-0.56)\end{array}$ & $\begin{array}{l}6.490 \\
(1.21)\end{array}$ \\
\hline Landlockedness & $\begin{array}{l}-0.021 \\
(-0.05)\end{array}$ & - & - & $\begin{array}{l}-11.717 \\
(-0.50)\end{array}$ \\
\hline Financial Development & $\begin{array}{l}-0.010 \\
(-0.55)\end{array}$ & $\begin{array}{c}-0.079^{* * *} \\
(-2.67)\end{array}$ & $\begin{array}{l}-0.278 \\
(-1.52)\end{array}$ & $\begin{array}{l}-0.319 \\
(-1.11)\end{array}$ \\
\hline FDI & $\begin{array}{l}0.021 \\
(0.29)\end{array}$ & $\begin{array}{l}-0.022 \\
(-0.28)\end{array}$ & $\begin{array}{c}-0.768^{* *} \\
(-2.28)\end{array}$ & $\begin{array}{c}-1.301^{* *} \\
(-2.51)\end{array}$ \\
\hline 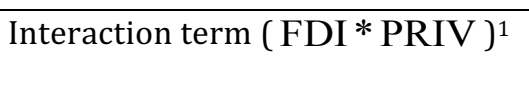 & $\begin{array}{l}0.002 \\
(0.62)\end{array}$ & $\begin{array}{l}0.003 \\
(1.07)\end{array}$ & $\begin{array}{l}0.036^{*} \\
(1.68)\end{array}$ & $\begin{array}{c}0.061^{* * *} \\
(2.64)\end{array}$ \\
\hline Number of groups & 1 & 36 & 35 & 36 \\
\hline Number of observations ${ }^{2}$ & 230 & 230 & 193 & 230 \\
\hline $\mathrm{R}^{2}$ (adjusted) & 0.17 & 0.38 & - & - \\
\hline Prob $>$ F & 0.00 & 0.00 & 0.14 & 0.03 \\
\hline Serial correlation test ( $\mathrm{p}$-value) & - & - & 0.104 & 0.057 \\
\hline Sargan test (p-value) & - & - & 0.599 & 0.838 \\
\hline
\end{tabular}

Notes: OLS, FE, DIFF GMM and SYS GMM refer to the ordinary least square, fixed effects, difference GMM and system GMM models, respectively. Heteroskedasticity-adjusted t-values for the OLS and fixed effects regressions and z-values for the dynamic panel regressions are reported below estimated coefficient values. $*^{* *},{ }^{* *}$, and ${ }^{*}$ indicate significance at $1 \%, 5 \%$, and $10 \%$, respectively. The null hypothesis of the serial correlation test is that the errors in the first difference regression exhibit no second-order autocorrelation, while the null hypothesis of the Sargan test is that the overidentifying restrictions are valid.

${ }^{1}$ FDI*PRIV represents the interaction term of FDI to GDP and private credit to GDP percentages.

${ }^{2}$ Panel estimations use 3-year periods.

The negative and significant estimate of the individual FDI term implies that there will be a positive effect of FDI on economic growth only if the development of the banking sector with respect to private credit has reached a certain level. Thus, we determine the threshold level of private credit as percentage of GDP beyond which FDI would begin to have a positive effect on economic growth in the SSA region following previous studies such as Carkovic and Levine (2002) and Hermes and Lensink (2003). To achieve this, we differentiate the model presented 
in regression 4 (that is, the system GMM results) of Table 5 with respect to FDI. The result is: $\triangle G R O W T H / \triangle F D I=-1.301+0.061(* P R I V)$

Setting the above equation equal to zero, the threshold level is thus calculated as PRIV $=(1.301 / 0.061)=21.33$. Thus, the results imply that FDI will have a positive effect on economic growth in SSA countries in which private credit as a percentage of GDP exceeds $21.33 \%$. The threshold value provides great insight regarding why FDI does not have a significant direct impact on economic growth in SSA as only 6 countries meet the threshold criterion (in terms of the average value of PRIV/GDP over the sample period) in the region. These countries and their respective financial development levels with respect to private credit include Kenya (24.36\%); Mauritius (63.03\%); Namibia (41.88\%); Senegal (22.15\%); South Africa (66.51\%) and Zimbabwe (25.91\%).

\section{Money Supply Channel}

Table 6 assesses whether the degree of monetization of the financial system influences the FDIgrowth relationship in SSA. The OLS and fixed effect estimates respectively find positive and negative effects that are insignificant on the role of the M2 variable in the FDI-growth relationship. However, the difference GMM regression yields a positive coefficient of 0.049 , which is significant at the $5 \%$ level. This result is supported by the most preferred model - the system GMM - which indicates a coefficient of 0.038 for the interaction term. We notice that the coefficient value produced by the FDI-private credit interaction term in the system GMM model is higher than that of the FDI-M2 interaction term of the same model. 
Table 6: The Complementary Effect of Banking Sector Development and FDI (Money Supply Channel)

Dependent variable: Growth rate of per capita GDP

\begin{tabular}{|c|c|c|c|c|}
\hline Conditioning information set & $\begin{array}{c}1 \\
\text { OLS }\end{array}$ & $\begin{array}{c}2 \\
\mathrm{FE}\end{array}$ & $\begin{array}{c}3 \\
\text { DIFF GMM }\end{array}$ & $\begin{array}{c}4 \\
\text { SYS GMM }\end{array}$ \\
\hline Constant & $\begin{array}{l}4.404^{*} \\
(1.69)\end{array}$ & $\begin{array}{l}1.622 \\
(0.71)\end{array}$ & - & $\begin{array}{l}29.834 \\
(0.84)\end{array}$ \\
\hline Initial income per capita & $\begin{array}{c}-0.512^{* *} \\
(-2.15)\end{array}$ & - & - & $\begin{array}{l}-2.212 \\
(-0.46)\end{array}$ \\
\hline Population & $\begin{array}{l}46.758 \\
(1.04)\end{array}$ & $\begin{array}{l}54.036 \\
(0.90)\end{array}$ & $\begin{array}{l}224.86 \\
(0.51)\end{array}$ & $\begin{array}{c}216.407 \\
(0.99)\end{array}$ \\
\hline Government consumption & $\begin{array}{l}-0.021 \\
(-0.66)\end{array}$ & $\begin{array}{c}-0192^{* * *} \\
(-2.77)\end{array}$ & $\begin{array}{l}-1.374^{*} \\
(-1.67)\end{array}$ & $\begin{array}{l}-1.133 \\
-1.58)\end{array}$ \\
\hline Trade openness & $\begin{array}{l}0.016^{*} \\
(1.91)\end{array}$ & $\begin{array}{c}0.061^{* * *} \\
(3.16)\end{array}$ & $\begin{array}{l}0.158^{*} \\
(1.70)\end{array}$ & $\begin{array}{c}0.173^{* *} \\
(2.27)\end{array}$ \\
\hline Democracy & $\begin{array}{c}0.034^{* * *} \\
(3.36)\end{array}$ & $\begin{array}{c}0.046^{* * *} \\
(3.38)\end{array}$ & $\begin{array}{l}-0.036 \\
(-0.35)\end{array}$ & $\begin{array}{l}-0.045 \\
(-0.71)\end{array}$ \\
\hline Government effectiveness & $\begin{array}{c}1.378^{* * *} \\
(3.22)\end{array}$ & $\begin{array}{c}2.377^{* *} \\
(2.39)\end{array}$ & $\begin{array}{l}8.542 \\
(0.93)\end{array}$ & $\begin{array}{l}6.810^{*} \\
(1.75)\end{array}$ \\
\hline Landlockedness & $\begin{array}{l}-0.122 \\
(-0.27)\end{array}$ & - & - & $\begin{array}{c}-12.887 \\
(-0.71)\end{array}$ \\
\hline Financial Development & $\begin{array}{l}-0.016 \\
(-0.82)\end{array}$ & $\begin{array}{l}-0.044^{*} \\
(-1.89)\end{array}$ & $\begin{array}{l}-0.197 \\
(-0.77)\end{array}$ & $\begin{array}{l}-0.188 \\
(-1.06)\end{array}$ \\
\hline FDI & $\begin{array}{l}0.054 \\
(0.55)\end{array}$ & $\begin{array}{l}-0.024 \\
(-0.24)\end{array}$ & $\begin{array}{c}-1.777^{* *} \\
(-2.02)\end{array}$ & $\begin{array}{c}-1.388^{* *} \\
(-2.33)\end{array}$ \\
\hline Interaction term $(\mathrm{FDI} * \mathrm{M} 2)^{1}$ & $\begin{array}{c}-0.0001 \\
(-0.05)\end{array}$ & $\begin{array}{l}0.002 \\
(0.88)\end{array}$ & $\begin{array}{c}0.049^{* *} \\
(2.09)\end{array}$ & $\begin{array}{c}0.038^{* *} \\
(2.42)\end{array}$ \\
\hline Number of groups & 1 & 36 & 35 & 36 \\
\hline Number of observations ${ }^{2}$ & 230 & 230 & 193 & 230 \\
\hline $\mathrm{R}^{2}$ (adjusted) & 0.17 & 0.37 & - & - \\
\hline Prob $>$ F & 0.00 & 0.00 & 0.00 & 0.03 \\
\hline Serial correlation test ( $p$-value) & - & - & 0.089 & 0.132 \\
\hline Sargan test (p-value) & - & - & 0.773 & 0.904 \\
\hline
\end{tabular}

Notes: OLS, FE, DIFF GMM and SYS GMM refer to the ordinary least square, fixed effects, difference GMM and system GMM models, respectively. Heteroskedasticity-adjusted t-values for the OLS and fixed effects regressions and z-values for the dynamic panel regressions are reported below estimated coefficient values. ${ }^{* * *}, * *$, and $*$ indicate significance at $1 \%, 5 \%$, and $10 \%$, respectively. The null hypothesis of the serial correlation test is that the errors in the first difference regression exhibit no second-order autocorrelation, while the null hypothesis of the Sargan test is that the overidentifying restrictions are valid.

1FDI*M2 represents the interaction term of FDI to GDP and M2 to GDP percentages.

${ }^{2}$ Panel estimations use 3-year periods.

As computed for the private credit channel above, we also determine the threshold level of M2 as percentage of GDP beyond which FDI would begin to have a positive effect on economic growth in the SSA region. Thus, we differentiate the model presented in regression 4 (that is, the system GMM results) of Table 6 with respect to FDI. The result is:

$\triangle G R O W T H / \triangle F D I=-1.388+0.038\left({ }^{*} M 2\right)$

Setting the above equation equal to zero, the threshold level is calculated as 
$\mathrm{M} 2=(1.388 / 0.038)=36.53$. Thus, the results imply that FDI will have a positive effect on economic growth in SSA countries with M2 as a percentage of GDP exceeding $36.53 \%$. Also, this probably explains why the FDI-economic growth relationship fails to yield the expected positive and significant direct effect as only 7 countries meet the threshold criterion (in terms of the average value of M2/GDP over the sample period). These countries and their respective financial development levels with respect to M2 as percentage of GDP include Kenya (36.84\%); Lesotho (37.02\%); Mauritius (85.11\%); Namibia (40.94\%); Seychelles (71.33\%); South Africa (63.16\%) and Zimbabwe (41.87\%).

Notice that except Lesotho and Seychelles, all these countries also attain the threshold level for private credit.

\section{Implication of Results}

Generally, the analysis on the causal relationship between banking sector development and FDI in SSA reveals that banking sector development has a positive impact on FDI in SSA. Also a case of perfect complementarity whereby banking sector development and FDI have positive causal effect on each other is only existent in the low-income sub-sample of the region. The result contradicts that of Soumaré and Tchana (2011), which finds an otherwise inconclusive relationship between banking sector development and FDI, but a bidirectional causality between stock market development and FDI in 29 emerging markets.

Also the study reveals that FDI does not have an independently positive and significant effect on economic growth in SSA, but rather, an indirect positive impact obtained through banking sector development. In essence, banking sector development, via credit by financial intermediaries to the private sector (i.e., private credit) and money and quasi money (i.e., M2), generally enhances the growth effect of FDI in the region. The implication of this finding is that countries which have sufficiently high amounts of these indicators relative to the size of their economies, i.e., GDP would derive the growth benefits of FDI as opposed to countries which have relatively shallow levels. Our empirical analysis shows that only 8 (Kenya, Mauritius, Namibia, Senegal, Lesotho, Seychelles, South Africa and Zimbabwe) out of the 37 SSA countries investigated demonstrate the absorptive capacity in terms of banking sector development so much as to upturn the generally insignificant or even negative effect of FDI on economic growth in the region.

Two notable characteristics dominate the 8 countries that meet the banking sector absorptive capacity criteria. First, with the exception of Zimbabwe, they are all middle income countries. This emphasizes the correlation between banking sector development and the level of economic development as observed in Roe (2016). Second, these countries are relatively diversified in the SSA context, as distinct from the extractive sector based activities that generally typify SSA economies. Except South Africa and Zimbabwe, whose main revenue sources lie in the mining industry, these countries are diversified and attract FDI in a wide range of industries ranging from textiles to tourism. Notice that the list excludes mineral-based economies such as Angola, Nigeria, Sudan and Republic of Congo, which account for majority of the FDI in SSA. This realisation supports the notion that non-extractive FDI presents a better alternative to extractive FDI as a source of economic growth as noted by Akinlo (2004) and Amendolagine, Boly, Coniglio, and Prota (2013).

Our evidence on the banking sector channel supports previous studies such as Alfaro et al. (2004), Hermes and Lensink (2003), Sghaier and Abida (2013) and Agbloyor et al. (2014), but 
contradicts Carkovic and Levine (2002) which finds no positive and significant intermediating impact of financial intermediary development on the FDI-growth nexus.

\section{CONCLUSION AND POLICY RECOMMENDATIONS}

Based on the premise that the empirical findings on the effect of FDI on economic growth in SSA may be different from those of previous studies which focus on intercontinental datasets, we study this relationship by controlling for endogeneity, heterogeneity, lagged dependent variable, initial per capita GDP, and other relevant variables. We explore the theoretical framework that recognizes the existence of a well-developed domestic financial system as being necessary for attaining the positive economic growth effects of FDI.

The study finds that increase in FDI does not directly or independently lead to economic growth in SSA. Regarding the relationship between financial development and FDI, the study finds a causal relationship between banking sector development and FDI. This relationship is unidirectional, flowing from banking sector development to FDI in the full SSA and middleincome SSA samples, but bi-directional and stronger in the low-income SSA sample. The stronger finance-FDI relationship in the low-income sample supports previous studies, which find that investment responds faster to finance in more financially constrained environments. Lastly, the study finds that while FDI does not have a direct positive effect on economic growth in SSA, there is an indirect effect intermediated by the development of the financial system. Specifically, beyond certain threshold levels $21.33 \%$ of GDP for bank credits to the private sector and $36.53 \%$ of GDP for M2), FDI begins to cause economic growth in the region.

The study, therefore, concludes that the development of the banking sector of the domestic financial system is a fundamental requirement for enhancing the effects of FDI on economic growth in the SSA region.

A crucial finding in this study is that lack of finance is a fundamental constraint to FDI, especially in the low-income countries of SSA. The attraction of FDI and the diffusion of its technology benefits require adequate finance in the domestic economy. Indeed, the complementary relationship between banking sector development and FDI induces a stronger link between FDI and growth. It is, therefore, necessary for SSA economies to enthusiastically pursue policies that will boost the development of their banking sectors so as to realize the benefits of FDI. Hence, the study recommends that strategies toward the attraction of foreign capital must be complemented by measures to boost the absorptive capacity of the SSA host countries in in terms of financial development.

\section{References}

Abrigo, M.R.M. and Love, I. (2015), Estimation of Panel Autoregression in Stata: A Package of Programs, Working Paper, University of Hawaii, USA.

Acemoglu, D., Jackson, S. and Robinson, J. (2003), 'Reversal of fortune: Geography and institutions in the making of the modern world income distribution', Quarterly Journal of Economics, Vol. 118, pp. 1231-94.

Adams S. (2009), 'Foreign Direct Investment, Domestic Investment, and Economic Growth in Sub-Saharan Africa', Journal of Policy Modeling, (31), pp. 939-49.

Agbloyor, E., Abor, J., Adjasi, C., and Yawson, A. (2014), 'Private Capital Flows and Economic Growth in Africa: The Role of Domestic Financial Markets', International Financial Markets, Institutions and Money, Vol. 30, pp. 137-152.

Aitken, B. and Harrison, A. (1999), 'Do Domestic Firms Benefit from Direct Foreign Investment? Evidence from Venezuela', American Economic Review, Vol. 89, No. 3, pp. 605-18.

Akinlo, A.E. (2004), 'Foreign Direct Investment and Growth in Nigeria: An Empirical Investigation', Journal of Policy Modeling, Vol. 26, pp. 627-39. 
Akinlo, A.E. and Egbetunde, T. (2010), 'Financial Development and Economic Growth: The Experience of 10 SubSaharan African Countries Revisited', The Review of Finance and Banking, Vol. 2, No. 1, pp. 17-28.

Alfaro, L., A. Chanda, S. Kalemli-Ozcan, and S. Sayek. (2004), 'FDI and Economic Growth, the Role of Local Financial Markets', Journal of International Economics, Vol. 64, pp. 113-134.

Allen, F. Carletti, E. Cull, R. Qian, J., and Senbet, L. (2010), “The African Financial Development Gap”, Mimeo. Amendolagine, V., Boly, A., Coniglio, N.D., and Prota, F. (2013), 'FDI and Local Linkages in Developing Countries: Evidence from Sub-Saharan Africa', World Development, Vol. 50, pp. 41-56.

Arellano, M. and Bond, S. (1991), 'Some Tests of Specification for Panel Data: Monte Carlo Evidence and an Application to Employment Equations', Review of Economic Studies, Vol. 58, No. 2, pp. 277-97.

Arellano, M. and Bover, 0. (1995), 'Another Look at Instrumental Variables Estimation of Error-component Models', Journal of Econometrics, Vol. 68, pp. 29-51.

Balasubramanyam, V.N., Sapsford, D., and Salisu, M. (1996), 'Foreign Direct Investment and Growth in EP and IS Countries', Economic Journal, Vol. 106, pp. 92-105.

Blomström, M., Lipsey, R.E., and Zejan, M. (1992), 'What explains Developing Country Growth', National Bureau of Economic Research (NBER), Working Paper \#4132.

Blundell, R. and S. Bond. (1998), 'Initial conditions and moment restrictions in dynamic panel-data models', Journal of Econometrics, Vol. 87, pp. 115-43.

Borensztein, E., De Gregorio, J. and Lee, J-W. (1998), 'How does foreign direct investment affect economic growth', Journal of International Economics, Vol. 45, pp. 115-35.

Cameron, A.C. and Trivedi, P.K. (2009), Microeconometrics Using Stata, Stata Press, Texas.

Carkovic, M. and Levine, R. (2002), “Does Foreign Direct Investment Accelerate Economic Growth?” in Does Foreign Direct Investment Promote Development? T. Moran, E. Graham and M. Blomström (eds), Peterson Institute for International Economics and Center for Global Development, Washington, DC.

Center for Systemic Peace: Polity IV dataset version 2013. Retrieved from Polity IV Project: www.systemicpeace.org. Accessed in May, 2014.

Choong, C., Yusop, Z. and S. Soo. (2004), 'Foreign Direct Investment and Economic Growth in Malaysia: The Role of Domestic Financial Sector', The Singapore Economic Review, Vol. 50, No. 2, pp. 245-68.

Cippolina, M., Giovannetti, G., Pietrovito, F. and Pozzolo, A.F. (2012), 'FDI and Growth: What Cross-Country Industry Data Say', The World Economy, Vol. 35, No. 11, pp. 1599-629.

Cohen W. and Levinthal, D. (1990), 'Absorptive capacity: A New perspective on learning and Innovation', Administrative Science Quarter, Vol. 35, pp. 128-52.

Dunning, J.H. (1980), 'Toward an Eclectic Theory of International Production: Some Empirical Tests', Journal of International Business Studies, Vol. 11, No. 1, pp. 9-31.

Fama, E. (1980), 'Banking in the Theory of Finance', Journal of Monetary Economics, Vol. 6, pp. 39-57.

Fayerweather, J. (1982), International Business Strategy and Administration, Ballinger Cambridge, Massachusetts.

Görg, H. and E. Strobl. (2005), 'Spillovers from Foreign Firms through Worker Mobility: An Empirical Investigation', Scandinavian Journal of Economics, Vol. 107, No. 4, pp. 693-709.

Görg, H. and Greenaway, D. (2004), 'Much Ado about Nothing? Do Domestic Firms really Benefit from Foreign Direct Investment?' World Bank Research Observer, Vol. 19, pp. 171-97.

Hausman, J. A. (1978), 'Specification Tests in Econometrics', Econometrica, Vol. 46, No. 6, pp. 1251-72.

Hermes, N. and Lensink, R. (2003), 'Foreign Direct Investment, Financial Development and Economic Growth', Journal of Development Studies, Vol. 40, No. 1, pp. 142-63.

Holtz-Eakin, D., Newey, W. and Rosen, H.S. (1988), 'Estimating Vector Autoregressions with Panel Data', Econometrica, Vol. 56. No. 6, pp. 1371-95.

Honohan, P. and Beck, B. (2007), Making Finance Work for Africa, World Bank, Washington, DC, USA.

Hubbard, G. (1998), 'Capital-market Imperfections and Investment', Journal of Economic Literature, Vol. 36, No. 1, pp. 193-225. 
Kaufmann, D., Kraay, A. and Mastruzzi, M. (2010), "The Worldwide Governance Indicators: Methodology and Analytical Issues", Policy Research Working Paper No. 5430, World Bank. Retrieved from http://ssrn.com/abstract=1682130

King R. G., Levine R. (1993), 'Finance and Growth: Schumpeter Might Be Right', The Quarterly Journal of Economics, Vol. 108, pp. 717-38.

Levine, R. (2005), 'Finance and Growth: Theory and Evidence', in Handbook of Economic Growth, P. Aghion and S.N. Durlauf (eds), Elsevier.

Levine, R., Loayza, N., and Beck, T. (2000), 'Financial Intermediation and Growth: Causality and Causes', Journal of Monetary Economics, Vol. 46, pp. 31-77.

Li, X. and Liu, X. (2005), 'Foreign Direct Investment and Economic Growth: An Increasingly Endogenous Relationship', World Development, Vol. 33, No. 3, pp. 393-407.

Lipsey, R., and Sjöholm, F. (2005), "The Impact of Inward FDI on Host Countries: Why Such Different Answers?" in Does Foreign Direct Investment Promote Development? T. Moran, E. Graham and M. Blomström (eds), Peterson Institute for International Economics and Center for Global Development, Washington, DC.

Love, I. (2003), 'Financial Development and Financing Constraints: International Evidence from the Structural Investment Model', Review of Financial Studies, Vol. 16, pp. 765-91.

Love, I., and Zicchino, L. (2006), 'Financial Development and Dynamic Investment Behavior: Evidence from Panel VAR', The Quarterly Review of Economics and Finance, Vol. 46, No. 2, pp. 190-210.

Marcin, K. (2007), 'How Does FDI Affect Productivity of Domestic Firms? The Role of Horizontal and Vertical Spillovers, Absorptive Capacity, and Competition', The Journal of International Trade and Economic Development, Vol. 17, No. 1, pp. 155-73.

Morgan, R.E. and Katsikeas, C.S. (1997), 'Theories of International Trade, Foreign Direct Investment and Firm Internationalization: A Critique', Management Decision, Vol. 35, No. 1, pp. 68-78.

Nguyen, H., Duysters, G., Patterson, J. and Sander, H. (2009), “Foreign Direct Investment Absorptive Capacity Theory", Retrieved from https://smartech.gatech.edu/bitstream/handle/1853/35267/1238510767_HN.pdf

Nunnenkamp, P. (2004) To what Extent can Foreign Direct Investment help Achieve International Development Goals? Blackwell, Oxford, United Kingdom.

Redding, S. and Venables, A. (2004), 'Economic Geography and Institutional Inequality', Journal of International Economics, pp. 53-82.

Rodrik, D., Subramanian, A., and Trebbi, F. (2002), 'Institutions Rule: The Primacy of Institutions over Geography and Integration in Economic Development', National Bureau of Economic Research (NBER) Working Paper 9305, Cambridge, Massachusetts, USA.

Roe, A.R. (2016), 'Financial Systems in New Middle-Income African Economies: The Opportunities and the Risks', Working Paper 2016/89, The United Nations University World Institute for Development Economics Research (UNU-WIDER), Helsinki, Finland.

Roodman, D. (2009), 'How to do xtabond2: An Introduction to Difference and System GMM in Stata', The Stata Journal, Vol. 9, No. 1, pp. 86-136.

Saggi, K. (2002), 'International Technology Transfer and Economic Development', in Development, Trade, and the WTO, B. Hoekman, A. Mattoo, and P. English (eds), World Bank, Washington DC.

Sghaier, I.M. and Abida, Z. (2013), 'Foreign Direct Investment, Financial Development and Economic Growth: Empirical Evidence from North African Countries', Journal of International and Global Economic Studies, Vol. 6, No. 1, pp. 1-13.

Smeets, R. (2008), 'Collecting the Pieces of the FDI Knowledge Spillovers Puzzle', World Bank Research Observer, Vol. 23, No. 2, pp. 107-38.

Söderbom, M., Teal, F., Eberhardt, M., Quinn, S. and Zeitlin, A. (2015), Empirical Development Economics, Routledge, New York.

Soumaré, I. and Tchana, F.T. (2011), 'Causality between FDI and Financial Market Development: Evidence from Emerging Markets', retrieved from https://mpra.ub.uni-muenchen.de/31328/

United Nations Conference on Trade and Development (UNCTAD) (1998), World Investment Report: Trends and Determinants, New York and Geneva. 
Olagbaju, I. O., \& Akinlo, A. E. (2018). FDI And Economic Growth Relationship In Sub-Saharan Africa: Is The Domestic Financial System A Significant Intermediator? Archives of Business Research, 6(5), 90-112.

United Nations Conference on Trade and Development (UNCTAD) (2000), Crossborder Mergers, and Acquisitions and Development, World Investment Report, United Nations, New York and Geneva. 